\title{
Article
}

\section{Surrogacy tourism: the ethical and legal challenges}

\author{
Gunputh, Rajendra Parsad and Choong, Kartina Aisha
}

Available at http://clok.uclan.ac.uk/13791/

Gunputh, Rajendra Parsad and Choong, Kartina Aisha ORCID: 0000-00019407-1771 (2015) Surrogacy tourism: the ethical and legal challenges. International Journal of Tourism Sciences, 15 (1-2). pp. 16-21. ISSN 1598-0634

It is advisable to refer to the publisher's version if you intend to cite from the work. http://dx.doi.org/10.1080/15980634.2015.1119388

For more information about UCLan's research in this area go to http://www.uclan.ac.uk/researchgroups/ and search for < name of research Group>.

For information about Research generally at UCLan please go to http://www.uclan.ac.uk/research/

All outputs in CLoK are protected by Intellectual Property Rights law, including Copyright law. Copyright, IPR and Moral Rights for the works on this site are retained by the individual authors and/or other copyright owners. Terms and conditions for use of this material are defined in the policies page.

\section{CLoK}

Central Lancashire online Knowledge www.clok.uclan.ac.uk 


\title{
SURROGACY TOURISM: THE ETHICAL AND LEGAL CHALLENGES
}

\author{
Rajendra Parsad Gunputh \\ Faculty of Law and Management \\ University of Mauritius \\ Réduit, Mauritius
}

\author{
\& Kartina Aisha Choong \\ Lancashire Law School \\ University of Central Lancashire \\ Preston, UK
}

\begin{abstract}
Although surrogacy seemed to have been practised since ancient times, its resurgence in the contemporary era has been nothing short of phenomenal. With advances made in reproductive technology, it is now possible to fertilise eggs and sperms in laboratories and have the embryo transferred into the womb of a surrogate mother for gestation. Through a combination of push and pull factors, this possibility of gestational surrogacy has led to the meteoric rise of cross-border surrogacy. This paper seeks to highlight the ethical and legal challenges associated with the practice, and calls for better legal oversight at international level.
\end{abstract}

Keywords: surrogacy; medical tourism; reproductive ethics; cross-border healthcare; bioethics; medical law

\section{INTRODUCTION}

Surrogacy has been defined as the practice where one woman carries a child on behalf of another with the intention of handing over the child after birth (Warnock, 1984). Derived from the Latin word 'surrogatus' which means a 'substitute' or 'in place of another' (Mahon, 2009), it is believed to have been carried out since Biblical times (Genesis 16: 1-4; Blyth \& Farrand, 2005). The 1980s saw the revival of interest as well as a revolution in the practice with the arrival of in vitro fertilization (IVF) technology. As this technique allows for eggs to be fertilized with sperm inside a laboratory before the fertilized egg or embryo is transferred to the womb to grow (NHS Choices, 2015), it opens up the door for gestational surrogacy.

Thus unlike traditional surrogacy where the surrogate mother is also the biological mother of the child, IVF enables the commissioning parents' own eggs and sperms to be fertilized and transferred into the surrogate's womb for gestation. The surrogate mother would therefore have no genetic ties with the child while an infertile couple has an opportunity to have a child who is genetically theirs (Lee, 2009; Jadva \& Imrie, 2014). The technique has also opened up the possibility of the fertilization and subsequent transfer of the commissioning mother's egg with a donor's sperm; a donor's egg with the commissioning father's sperm; or even the use of both donated eggs and donated sperms. This has therefore also made it possible for single people or homosexual couples to become parents (Brugger, 2012; Pennings, 2002). All these gave rise to commercial surrogacy where monetary compensation is paid to a woman to serve as a gestational surrogate (Lee, 2009). However, numerous factors have served as barriers to entering into a commercial surrogacy arrangement domestically. There could perhaps be a lack of sufficiently skilled healthcare professionals and/or technological resources in the home country, or a strong desire on the part of the commissioning parents to protect their privacy (Palattiyil, Blyth, Sidhva \& 
Balakrishnan, 2010). Even if the relevant technology and personnel are available, some countries may exclude aspiring parents on the basis of age, marital status or sexual orientation (Palattiyil, Blyth, Sidhva \& Balakrishnan, 2010). A number of countries (e.g. France, Germany, Italy, Japan, Spain, Sweden, and a few states in the USA) have even placed a legal ban on surrogacy, while others (like Canada, New Zealand, the UK, and a number of states in Australia) have made commercial surrogacy illegal or heavily regulated (Ahmad, 2011; Callaghan \& Newson, 2014; Cohen, 2015; Lee, 2009). In addition, surrogacy may also be prohibitively expensive in certain countries.

These factors have triggered the proliferation of cross-border surrogacy. Infertile or homosexual couples desiring to be parents are increasingly attracted to transnational gestational surrogacy 'hubs' like India, Ukraine, Thailand, Russia and Slovenia. Demand is fuelled by factors like the decline in the numbers of children available for adoption locally; the availability of high quality reproductive healthcare and highly skilled personnel; significantly lower prices; and lax governmental regulation in those countries (Rimm, 2009). Thus in just over 3 decades, surrogacy tourism is now a multi-billion dollar industry. India, by far the country most frequented by such would-be parents, is reported to have an annual income of over USD2 billion derived from surrogacy alone (Choudhury, 2015). An official report from the country therefore described the industry as a "pot of gold" (Law Commission of India, 2009). The main reason behind India becoming the global centre of surrogacy (Ryznar, 2010) is because the costs of surrogacy there are substantially less than what they would cost in developed countries. For instance, the total cost of such services is approximately USD25,000 to USD30,000 in India (Mohapatra, 2012), when it would cost between USD70,000 and USD150,000 for the same to be procured in the USA (Lee, 2009). In addition to the provision of cost effective treatment, there are no elaborate paperwork or legal formalities involved - it being possible to arrange the entire transaction online via agencies (Schover, 2014), and there is legal recognition that the surrogacy arrangement is valid (Shetty, 2012). Worldwide, surrogacy tourism is now worth approximately USD6 billion a year (Mohapatra, 2012). In this paper, we seek to investigate some of the most pressing ethical and legal issues relating to this burgeoning industry.

\section{MORAL AND LEGAL COMPLEXITIES}

Surrogacy tourism, on the face of it, seems to lead to a mutually beneficial situation for all concerned. The infertile couple gets the child they long for; the surrogate mother can earn in 9 months what would otherwise take years to accumulate thus enabling a better quality of life (for instance, Indian surrogate mothers receive USD3,000-6,000 for their services compared to their usual annual income of around just USD500 - Palattiyil, Blyth, Sidhva \& Balakrishnan, 2010); and the country hosting the surrogacy enjoys economic growth. Lurking underneath, however, are numerous ethical and legal complexities. This part of the discussion will look at some of these issues as they relate to the surrogate mother; the commissioning parents; and the child.

\subsection{Surrogate Mothers}


Looking firstly at surrogate mothers, it is important to note that just as the commissioning parents in transnational gestational surrogacy typically come from highincome countries, those serving as gestational mothers usually come from low or middleincome countries where there is a very large pool of poor fertile women of childbearing ages (Kirby, 2014). There is therefore a marked economic inequality between the two parties (Pande, 2011). Further, there is a gulf between the surrogate mothers and the local doctors treating them in terms of class, level of education and social power (Deonandan, Green \& van Beinum, 2012). As such, they could be prompted by economic reasons and be subjected to undue influence or coercion from family members and doctors to take part (Mohapatra 2012; Palattiyil, Blyth, Sidhva \& Balakrishnan, 2010). This could put into question their voluntariness. Concerns have also been raised that unscrupulous intermediaries have lured and pushed these economically and educationally disadvantaged women into surrogate motherhood (Lee, 2009). Since many of those recruited as potential surrogate mothers are also illiterate (Deonandan, Loncar, Rahman \& Omar, 2012), they are easy preys to racketeers and traffickers (Dasgupta \& Das Dasgupta, 2014). Consequently, there have been reports that surrogate mothers in such countries are misused and exploited (Siva, 2011).

Additionally, since surrogacy arrangements are brokered in a purely capitalist milieu, full and frank information-disclosure usually takes a back seat to the generation of new business (Deonandan, Loncar, Rahman \& Omar, 2012). Many of the women are therefore not made aware of the physical and mental health risks associated with being a surrogate mother. These include the possibilities of: having to accept multiple embryos to maximise successful implantation and undergoing selective reduction abortion (Deonandan, Green \& van Beinum, 2012); having to undergo nonemergency caesarean sections at the direction of the commissioning parents (Vincent \& Aftandilian, 2013); missing their own children when living in surrogacy hostels during their pregnancy (Kirby, 2014; Mohapatra, 2012); undergoing postnatal depression (Palattiyil, Blyth, Sidhva \& Balakrishnan, 2010) after giving up a child with whom they feel a sense of attachment to (Lee, 2009; Macer, 2014; Riley, 2007); and even death (Kirby, 2014). Neither do they receive any counselling before, during or after pregnancy (Vincent \& Aftandilian, 2013). As the clinics operate along commercial lines, there is no incentive to spend further resources on the surrogate mother once she has performed what she was employed for i.e. to deliver a healthy child (Deonandan, Green \& van Beinum, 2012). In the event where limited information was provided, no efforts were made to ascertain if they understand what they have been told (Kirby, 2014).

Indeed the surrogacy contract itself is usually written in English, a language which very few, if any, of the women can understand (Kirby, 2014). It has been reported that many authorize the contract with a thumbprint as they are unable to read and write (Mohapatra, 2012). The terms and conditions are exclusively determined by infertility brokers and the doctors who own and operate the clinics where the surrogacy will take place (Kirby, 2014). The surrogate women therefore played no part in negotiating the terms of the contract including the amount they will be paid (Mohapatra, 2012). Nor are they legally represented (Deonandan, Green \& van Beinum, 2012). As such, only a small amount of the surrogacy fee goes to the surrogate mother. In India, for instance, the amount received by the surrogates are only around $10 \%$ of the amount paid by the commissioning parents and in Ukraine this is around 30\% (Mohapatra, 2012). Thus they may not be receiving a fair price in the regional and local contexts (Deonandan, Green \& van Beinum, 2012). Had they been aware of the risks involved and received legal representation, a higher price could perhaps be negotiated (Mohapatra, 2012). Moreover, they will not receive any compensation if the pregnancy fails as many only received their payment after they have given birth (Goodwin, 2013). Other considerations which are often overlooked in the contract are issues like whether they will 
still be paid if they are asked to abort the fetus or if the commissioning parents change their minds before or after the child is born; are they insured; do they have a right to terminate the pregnancy; and will there be aftercare or compensation if they suffer injury or contract an infection as a result of their participation (Schover, 2014). In view of the discussion above, it is doubtful if they entered into the surrogacy arrangement on an informed and voluntary basis. Being a surrogate is therefore a form of labour rather than a result of an autonomous decision (Mohapatra, 2012; Vora, 2009).

\subsection{Commissioning Parents}

As for the commissioning parents, they too risk many uncertainties. Not least of which are the potential legal pitfalls (Gamble, 2009). Because of the differing laws in their own and in the foreign country, they may not know issues like: the legality and validity of the surrogate contract; whether they would have any legal recourse in the event where the surrogate mother changes her mind; whether they would still have to pay the surrogacy fee if the child dies during pregnancy; and if they can refuse to take the child if he or she was born disabled (Lee, 2009; Mohapatra, 2012).

Even where the pregnancy and birth are successful and the child was handed over as agreed, there are immigration issues that need to be dealt with when efforts are made to bring the child back to the commissioning parents' home country (Charrot, 2014). Will their domestic law allow the repatriation of the child; will they be recognised as the child's legal parents and will the child be able to have their nationality? It is known that even when the commissioning parents obtained a court order in the child's country of birth which recognises or enforces the surrogacy arrangement, this order may not be recognised in their country (Charrot, 2014). Likewise with birth certificates which are issued in the country of the child's birth. Some countries have even made it illegal for their citizens to engage in international surrogacy (e.g. France and some states in Australia)(Callaghan \& Newson, 2014). If the commissioning couple is from one of these countries, they could even be prosecuted for going abroad to evade their own laws (Charrot, 2014). In such situations, the child could be ordered to be returned to their country of birth (Lee, 2009). Countries that ban surrogacy may also refuse to register the child in the country's registry thereby resulting in them not having any recognizable legal parents (Cohen, 2015).

\subsection{The Child}

In light of the above, the child is therefore born into uncertain family situations (Davis, 2012). It goes without saying that the child is therefore the most vulnerable party among all involved. Who will be considered as his or her parents; will he or she be legitimate with rights of inheritance; and what about issues like religion and domicile (Ahmad, 2011)? Further, what if the child was disabled and rejected by the commissioning parents as in the high profile case of Baby Gammy (Schover, 2014)? What if the commissioning parents change their minds or got divorced before the child was born as in the case of Baby Manji, another high-profile case (Baby Manji Yamada v Union of India \& Others 2008; Parks, 2010)? The lack of screening of who could commission a child may also leave the child with unfit parents (Lee, 2009). Since difficulties are faced when determining the child's legal parentage, the child even risks being stateless thus devoid of recognition by or protection of any State (Kanics, 2014; Parks, 2010; Re X and Y (Foreign Surrogacy)[2009]). 


\section{CONCLUSION}

Surrogacy tourism is one of the fastest growing industries in the world today (Steiner, 2013). However, as discussed, there are numerous ethical and legal pitfalls that need to be considered. Yet this global and lucrative market has developed with few checks and balances in place (Smerdon, 2008-2009). There is currently no international treaty that regulates surrogacy tourism (Vincent \& Aftandilian, 2013). There is only a web of conflicting national laws (Ramskold \& Posner, 2013). The industry is therefore left to regulate itself and any guidelines or conditions are often driven by the market forces of demand and supply (Deonandan \& Bente, 2014). But the potential for exploitation and harm to the surrogate mother, commissioning parents and above all, the child, is far too high that self-regulation cannot be the long-term answer (Lee, 2009). Rather, there is a need for legal oversight of the activity at international level.

\section{REFERENCES}

Ahmad, N. (2011). An international view of surgically assisted conception and surrogacy tourism. Medico-Legal Journal, 79(4), 135-145.

Baby Manji Yamada v Union of India \& Others [2008] INSC 1656.

Blyth, E. \& Farrand, A. (2005). Reproductive tourism - a price worth paying for reproductive autonomy? Critical Social Policy, 25(1), 91-114.

Brugger, K. (2011-2012). International law in the gestational surrogacy debate. Fordham International Law Journal, 35, 665-697.

Callaghan, S. \& Newson, A. (2014). Surrogacy, motherhood and baby Gammy. Bionews, 766.

Charrot, R. (2014). What do you need to know about surrogacy? Private Client Business, 1 , $39-43$.

Choudhury, C. A. (2015). The political economy and legal regulation of transnational commercial surrogate labour. Vanderbilt Journal of Transnational Law, 48(1), 1-65.

Cohen, I. G. (2015). Patients with passports: medical tourism, law and ethics. New York: Oxford University Press.

Dasgupta, S. \& Das Dasgupta, S. D. (eds.)(2014). Globalization and transnational surrogacy in India: outsourcing life. Maryland: Lexington Books.

Davis, E. (2012). The rise of gestational surrogacy and the pressing need for international regulation. Minnesota Journal of International Law, 21, 120-144.

Deonandan, R. \& Bente, A. (2014). Assisted reproduction and cross-border maternal surrogacy regulations in selected nations, British Journal of Medicine and Medical Research, 4(1), 225-236.

Deonandan, R., Green, S. \& van Beinum, A. (2012). Ethical concerns for maternal surrogacy and reproductive tourism. Journal of Medical Ethics, 38(12), 742-745.

Deonandan, R., Loncar, M., Rahman, P. \& Omar, S. (2012). Measuring reproductive tourism through an analysis of Indian ART clinic websites. International Journal of General Medicine, 5, 763-773.

Gamble, N. (2009). Crossing the line: the legal and ethical problems of foreign surrogacy. Reproductive BioMedicine Online, 19, 151-152. 
Goodwin, M. (2013). Reproducing hierarchy in commercial intimacy. Indiana Law Journal, $88,1289-1297$.

Jadva, V. \& Imrie, S. (2014). Children of surrogate mothers: psychological well-being, family relationships and experiences of surrogacy. Human Reproduction, 29(1), 90-96.

Kanics, J. (2014). Preventing and addressing statelessness in the context of international surrogacy arrangements. Tilburg Law Review, 19, 117-126.

Kirby, J. (2014). Transnational gestational surrogacy: does it have to be exploitative? American Journal of Bioethics, 14(5), 24-32.

Lee, R. L. (2009). New trends in global outsourcing of commercial surrogacy: a call for regulation. Hasting's Women Law Journal, 20, 275-300.

Macer, D. (2014). Ethical conditions for transnational gestational surrogacy in Asia. American Journal of Bioethics, 14(5), 1-2.

Mahon, M. M. (2009). Withdrawing and withholding life-prolonging therapies in children. In V. Ravitsky, A. Fiester \& A.L. Caplan (eds.), The Penn Center guide to bioethics (p. 484). New York: Springer Publishing Co.

Mohapatra, S. (2012). Stateless babies and adoption scams: a bioethical analysis of international commercial surrogacy. Berkeley Journal of International Law, 30, 412-450.

NHS Choices, 'IVF', available at http://www.nhs.uk/conditions/IVF/Pages/Introduction.aspx. Palattiyil, G., Blyth, E., Sidhva, D. \& Balakrishnan, G. (2010). Globalization and crossborder reproductive services: ethical implications of surrogacy in India for social work. International Social Work, 53(5), 686-700.

Pande, A. (2011). Transnational commercial surrogacy in India: gifts for global sisters? Reproductive BioMedicine Online, 23, 618-625.

Parks, J.A. (2010). Care ethics and the global practice of commercial surrogacy. Bioethics, 24(7), 333-340.

Pennings, G. (2002). Reproductive tourism as moral pluralism in motion. Journal of Medical Ethics, 28, 337-341.

Ramskold, L. A. H. \& Posner, M. P. (2013). Commercial surrogacy: how provisions of monetary remuneration and powers of international law can prevent exploitation of gestational surrogates. Journal of Medical Ethics, 39, 397-402.

Re X and Y (Foreign Surrogacy)[2009] 2 WLR 1274.

Riley, D. R. (2007). Surrogate pregnancy: a guide for Canadian prenatal health care providers. Canadian Medical Association Journal, 176(4) 483-485.

Rimm, J. (2008-2009). Booming baby business: regulating commercial surrogacy in India. University of Pennsylvania Journal of International Law, 30, 1429-1462.

Ryznar M. (2010). International commercial surrogacy and its parties. John Marshall Law Review, 43(4), 1009-1039.

Schover, L. R. (2014). Cross-border surrogacy: the case of baby Gammy highlights the need for global agreement on protections for all parties. Fertility and Sterility, 102(5), 1258-1259.

Shetty, P. (2012). India's unregulated surrogacy industry. Lancet, 380, 1633-1634.

Siva, N. (2011). Rise in assisted reproduction tourism in Asia threatens local medical services. British Medical Journal, 343, d5453.

Smerdon, U. R. (2008-2009). Crossing bodies, crossing borders: international surrogacy between the United States and India, Cumberland Law Review, 39, 15-85.

Steiner, L. M. (2013). The baby chase: how surrogacy is transforming the American family. New York: St Martin's Press.

Vincent, C. \& Aftandilian, A.D. (2013). Liberation or exploitation: commercial surrogacy and the Indian surrogate. Suffolk Transnational Law Review, 36, 671-682.

Vora, K., (2009). Indian transnational surrogacy and the commodification of vital energy. Subjectivity, 28, 266-278. 
Warnock, M. (1984). Report of the committee of inquiry into human fertilization and embryology, Cmnd 9314, HMSO. 